\title{
Targeted Drug Delivery in Pancreatic Cancer
}

\author{
Xianjun Yu ${ }^{1,2, \rrbracket}$, Yuqing Zhang ${ }^{1, \Uparrow}$, Changyi Chen ${ }^{1}$, Qizhi Yao ${ }^{1}$, and Min $\mathbf{L i}^{1}{ }^{1,}$ \\ ${ }^{1}$ Michael E. DeBakey Department of Surgery, Molecular Surgeon Research Center, Elkins Pancreas \\ Center, Baylor College of Medicine, Houston, Texas 77030, USA \\ ${ }^{2}$ Pancreatic Disease Institute, Huashan Hospital, Fudan University, Shanghai, China
}

\begin{abstract}
Effective drug delivery in pancreatic cancer treatment remains a major challenge. Because of the high resistance to chemo and radiation therapy, the overall survival rate for pancreatic cancer is extremely low. Recent advances in drug delivery systems hold great promise for improving cancer therapy. Using liposomes, nanoparticles, and carbon nanotubes to deliver cancer drugs and other therapeutic agents such as siRNA, suicide gene, oncolytic virus, small molecule inhibitor and antibody has been a success in recent pre-clinical trials. However, how to improve the specificity and stability of the delivered drug using ligand or antibody directed delivery represent a major problem. Therefore, developing novel, specific, tumor-targeted drug delivery systems is urgently needed for this terrible disease. This review summarizes the current progress on targeted drug delivery in pancreatic cancer, and provides important information on potential therapeutic targets for pancreatic cancer treatment.
\end{abstract}

\section{Keywords}

targeted drug delivery; pancreatic cancer

\section{Introduction}

Pancreatic cancer has the worst mortality rate and the lowest overall survival (OS) in all cancers. The incidence of pancreatic cancer is gradually increased with 42,470 predicated new cases in the United States in 2009, in which 35,240 will die. Only about $10 \%$ of patients are presented with resectable disease and are suitable for potentially curative surgery [1]. Even for patients who are qualified for surgery, aggressive metastasis often occurs after the operation, which is highly resistant to conventional chemotherapy and radiation therapy. Therefore, prognosis of pancreatic cancer is very poor, and the incidence almost equals with the mortality rate, with 5-year survival less than 5\%.Patients with locally advanced disease have 6-10 months of median survival, and patients with metastatic disease only have 3-6 months of median survival $[2,3]$. Novel strategies to treat this deadly disease are urgently needed.

(C) 2009 Elsevier B.V. All rights reserved.

*Address correspondence to: Michael E. DeBakey Department of Surgery Baylor College of Medicine One Baylor Plaza, Mail stop: BCM 391 Houston, TX 77030 Phone: (713) 798-3237 Fax: (713) 798-1705 minli@bcm.edu.

These authors made equal contributions to this article.

Publisher's Disclaimer: This is a PDF file of an unedited manuscript that has been accepted for publication. As a service to our customers we are providing this early version of the manuscript. The manuscript will undergo copyediting, typesetting, and review of the resulting proof before it is published in its final citable form. Please note that during the production process errors may be discovered which could affect the content, and all legal disclaimers that apply to the journal pertain. 
Chemotherapy is still the only option in metastatic pancreatic cancer treatment although at most of the times chemotherapy is purely palliative with minimal impact on survival [4]. Gemcitabine (2'-2'-difluorodeoxycytidine) represents the standard chemotherapy for all stages of pancreatic adenocarcinoma in the last decade [5]. However, neither gemcitabine alone nor gemcitabine-based combinational chemotherapy achieve a favorable outcome in advanced disease. New adjuvant therapy targeting at specific markers in pancreatic cancer using molecular approach may represent a promising strategy in the diagnosis and treatment of pancreatic cancer. Those molecular approaches have been rapidly developed in recent years, which include antisense oligonucleotides, RNA interference (RNAi), gene restoration, suicide gene therapy, small molecule inhibitors, antiangiogenic and matrix metalloproteinase inhibitors, oncolytic viral therapy, immunotherapy, and antibody therapy. Currently many of those approaches have not been tested in clinical applications, and most of the treatments are combined with standard chemotherapy or radiotherapy for maximum benefits [6]. In order to achieve ideal efficiency of chemotherapy or adjuvant therapies, effective delivery is a key issue in pancreatic cancer treatment. This review summarized the current progress on targeted drug delivery in pancreatic cancer including the therapeutic agents, vehicles, delivery routes, and targets for specific delivery to pancreas, and provides important information on new strategies for pancreatic cancer treatment.

\section{Therapeutic Agents}

In addition to the conventional chemotherapy drugs such as gemcitabine, fluorouracil (5-FU), and platinum agents (oxaliplatin, cisplatin, carboplatin), new therapeutic agents have been developed recently which target at cell surface receptors, ligands, transcriptional factors, mutant genes, or the immune system in pancreatic cancer. Those agents include small interfering RNAs (siRNAs), antisense nucleotides, suicide genes, toxins, oncolytic viruses, small molecule inhibitors, and antibodies through non-toxic, controlled released vectors such as liposomes, nanoparticles, and carbon nanotubes (Table 1) [7-13]. These therapeutic agents will provide a new perspective on pancreatic cancer treatment using molecular approaches.

\section{SiRNA}

RNA interference (RNAi) is a new technology and has become a powerful tool in silencing gene expression in most cells. siRNA or short hairpin RNA (shRNA) based therapy have shown great promise in many cancers. Targets for siRNA therapy are usually oncogenes, or genes that are important in tumor growth and metastasis such as key molecules in angiogenesis, survival, anti-apoptosis, and resistance to chemotherapy. A few examples using siRNA therapy to treat pancreatic cancer are listed below. In BxPC-3 cells, siRNA against matrix metalloproteinase-2 (MMP-2) suppressed the tumor cell adhesion and invasion [14]. Under hypoxic conditions, siRNA targeting HIF- $1 \alpha$ decreased pancreatic cancer cell proliferation and induced cell apoptosis [15]. A recent study showed that blocking the sphingosine kinase-1 activity using siRNA can sensitize the pancreatic cancer cells to gemcitabine treatment, indicating that development of a combinational therapy of siRNA with gemcitabine may represent a promising approach in pancreatic cancer treatment [16]. Our study also found that silencing of a zinc transporter ZIP4 by shRNA inhibits pancreatic cancer growth and significantly increases the survival of nude mice with pancreatic cancer xenografts [17]. A common limitation often seen in siRNA therapy is the unanticipated off-target effects that occur by siRNA recognition of other mRNA with partial homology, and non-specific silencing of genes in the normal tissues other than the target organ. Therefore, effective targeted delivery system is warranted in siRNA therapy [8]. 


\section{Gene therapy}

Gene therapy by expressing, restoring or inhibiting a particular gene of interest is expected to prevent or reverse the growth of cancer cells. In pancreatic cancer, transfection of the tumor suppressor gene p53 was found to suppress the growth of multiple human pancreatic cancer cell lines. Adenovirus mediated wild-type p53 gene therapy induced cancer cell apoptosis and suppressed tumor growth in a nude mouse subcutaneous model [18]. Moreover, reintroduction of p53 to pancreatic cancer cells which were previously treated with gemcitabine increased the cytotoxicity both in vitro and in vivo [19]. Xu el al has shown that efficient restoration of wild type p53 function in squamous cell carcinoma of the head and neck (SCCHN) cells through liposome delivery resulted in a significant increase in radiation-induced apoptosis which was proportional to the level of exogenous wild type p53 in the tumor cells. Intravenous administration of liposome-p53 sensitized established SCCHN nude mouse xenograft tumors to radiotherapy. The combination of systemic liposome-p53 gene therapy and radiation caused complete tumor regression and inhibition of their recurrence even 6 months after the end of the treatment [9]. Restoration of other tumor suppressor, somatostatin receptors (SSTRs), also inhibits pancreatic cancer growth. Our previous studies have shown that transfection of SSTR-1 induces cell cycle arrest and inhibits tumor growth in pancreatic cancer, and cotransfection of SSTR-1 and SSTR-2 further inhibits pancreatic cancer cell proliferation and renders pancreatic cancer cells responsive to somatostatin analogue treatment [20,21]. Other tumor suppressor genes used in gene therapy include Rb, p21, and p16 which regulate the G1 to S phase checkpoint during the cell cycle. Reestablishing the expression of those genes could restrain cancer cell proliferation [22].

\section{Suicide gene therapy}

Suicide gene therapy, also called prodrug system, is a two-step gene therapy, in which a suicide gene is delivered to the tumor first which will lead to the expression of an active enzyme. And a prodrug is subsequently administered which is cleaved and activated selectively by the suicide gene encoded enzyme [23]. Cytosine deaminase (CD) is a bacteria derived enzyme that converts the nontoxic agent 5-fluorocytosine (5-FC) to the active chemotherapeutic agent 5fluorouracil (5-FU). Transfection of the CD gene into BxPC-3 cells in combination with 5-FC treatment inhibited tumor growth in vivo [24]. Similarly, administration of microencapsulated genetically modified allogeneic cells, which expressed cytochrome P450, an enzyme that activates the chemotherapeutic agent ifosfamide to its cytotoxic form, led to local activation of systemically administered ifosfamide, and tumor reduction in a phase I/II trial in 14 pancreatic cancer patients. The median survival was doubled in the treatment group compared with the control, and 1-year survival was three times better [25]. The herpes simplex virus (HSV) thymidine kinase gene (HSV-TK) is the most widely studied gene for suicide gene therapy. HSVTK gene metabolizes the nontoxic prodrug, Gancyclovir (GCV), and turns it into a GCV triphosphate, the active form. This metabolite can incorporate into the DNA helix and inhibit both DNA synthesis and cell cycle progression, leading to apoptosis and cell death. HSV-TK gene delivery followed by GCV, was found to be effective on inhibiting tumor growth and metastasis of pancreatic cancer [26,27]. Tissue specific promoters are preferred in the suicide gene therapy in order to achieve maximal efficacy and minimal toxicity.

\section{Oncolytic virus therapy}

Replication-deficient oncolytic viruses are engineered to replicate only in tumor cells, which makes it an ideal therapeutic agent for cancer treatment. Those viruses kill tumor cells by a variety of mechanisms including direct cell lysis, cell-cell fusion, toxic proteins, and induction of antitumor immune responses $[6,13]$. Commonly used oncolytic viruses include adenovirus, herpes simplex virus, and reovirus. ONYX-015 is an E1B-deleted replication-selective adenovirus that preferentially replicates in malignant cells. A phase II clinical trial using 
ONYX-015 oncolytic adenovirus in patients with pancreatic cancer achieved favorable outcome (tumor reduction or stabilization) in about half of the patients [28]. Most oncolytic herpes simplex viruses (HSVs) are from type $1 \mathrm{HSV}$. Recently a novel oncolytic virus (FusOnH2) from the type 2 HSV has been developed. The FusOn-H2 virus hosts a deletion of the PK domain in the ICP10 gene, and only replicates in Ras activated cells such as pancreatic cancer cells. Delivery of FusOn-H2 through intraperitoneal route completely eradicated established orthotopic tumors in $75 \%$ of the animals and prevented local metastases [13]. Reovirus can also be used as an oncolytic agent targeting the activated Ras signaling pathway. In an immunocompetent animal model, reovirus treatment could inhibit the peritoneal dissemination of pancreatic cancer cells and decrease the liver metastasis. Immunohistochemical analysis revealed that reovirus replication was only seen within the tumor cells but not in the surrounding normal tissues [29-31].

\section{Small molecule inhibitors}

The first effective biological drug approved for the treatment of advanced pancreatic cancer was erlotinib (TarcevaTN), a small molecule Tyrosine Kinase Inhibitor, which was licensed by FDA in 2006 [32]. Erlotinib targets the intracellular domain of the epidermal growth factor receptor (EGFR), and has been shown to improve survival when used in combination with gemcitabine to treat metastatic pancreatic cancers [7,33]. Antiangiogenic agents have also been used in the treatment of pancreatic cancer due to the fact that they could overcome some drug resistance caused by insufficient penetration of cytotoxic chemotherapy in solid tumors. Other small molecule inhibitors include farnesyl transferase inhibitors, matrix metalloproteinase inhibitors, and COX 2 inhibitors [34].

\section{Antibody therapy}

More and more evidence suggest that the immune system plays an important role in the control of tumor progression. Immunotherapies especially antibody therapy have shown great promise in pancreatic cancer treatment. Many studies suggest that EGF and vascular endothelial growth factor (VEGF) pathways are activated in a large amount of human pancreatic cancers. EGFR and VEGF expression are associated with the prognosis of pancreatic cancer. It has been shown that anti-EGFR monoclonal antibodies including Cetuximab and Matuzumab inhibit the tumor growth and angiogenesis. Combination of anti-EGFR antibodies with gemcitabine or radiotherapy led to significant growth inhibition of pancreatic cancer cells compared with the single or double therapy [35]. In a recent case report, a patient with stage IV pancreatic cancer showed response to chemotherapy with the addition of bevacizumab, a recombinant humanized monoclonal antibody targeting VEGF, while initially was unresponsive to gemcitabine, 5-FU, irinotecan and cisplatin treatment [36]. This study demonstrated the benefit of bevacizumab used in combination with previously failed chemotherapy for pancreatic cancer. Anti-MUC1 antibody, (90)Y-DOTA-cPAM4, in combination with gemcitabine showed a significant inhibition of tumor growth and prolonged survival of the mice [37]. The in vitro study showed that another anti-MUC1 antibody (213)Bi-C595 was specifically cytotoxic to MUC1expressing pancreatic cancer cells compared with the controls [38]. Mesothelin (MSLN) is a tumor differentiation antigen that is highly expressed in human malignant tumors including pancreatic cancer $[39,40]$. Anti-MSLN antibody MORAb-009 kills MSLN expressing cell lines via antibody dependent cellular cytoxicity (ADCC). In addition, another anti-MSLN antibody SS1P in combination with chemotherapy drugs also play a critical role in anti-cancer therapy $[41,42]$.

\section{Drug Delivery Methods}

The most commonly used carriers for drug delivery in pancreatic cancer treatment include liposomes, nanoparticles, and carbon nanotubes. Those carriers can protect the drugs from 
degradation and will effectively deliver them to the target organs. The advantages of the carrier encapsulation of the drugs include increased drug solubility, prolonged drug exposure time, selective drug delivery to the target, improved therapeutic outcome, decreased toxic effects and low drug resistance.

\section{Liposomes}

Liposomes have been successfully used as pharmaceutical carriers for anti-cancer drugs. The liposomes contain lipid-based formulations to enhance the solubility of poorly soluble antitumor drugs, and vector-conjugated liposomal carriers can be used for specific targeted delivery to the designated tumor tissues [43]. Liposomes have been used to increase the concentrations of lipophilic drugs in aqueous media as well as preventing the encapsulated drugs from enzymatic degradation. The liposomal formulation of anti-cancer drugs such as Doxorubicin or 5-FU are usually stable for several months to several years [44,45]. In a phase I clinical study, a new liposomal cisplatin formulation, lipoplatin, showed an improved effect and reduced toxicity in advanced malignant tumors [46]. Administration of gemcitabine loaded pegylated liposome in human pancreatic cancer cell lines showed a significant reduction of cell viability compared with the gemcitabine alone [47]. In a SCID mouse model which bears BxPC-3 or PSN-1 xenografts, animals treated with gemcitabine loaded pegylated liposomes showed a survival advantage, enhanced systemic bioavailability and increased inhibition of tumor growth than gemcitabine alone, without obviously increased toxicity [47].

Traditionally, liposomes have also been used as a vector-conjugated carrier for gene transfection in vitro. DNA can be incorporated with cationic lipids and then transported into cancer cells for gene therapy. KAI1 gene, a metastasis suppressor gene, was transfected into pancreatic cancer cell line MIA PaCa-2 by liposome, which showed an inhibition of cancer metastasis [48]. Furthermore, liposome can also deliver siRNAs or shRNAs to silence oncogenes in pancreatic cancer. A liposome delivered siRNA targeting protein kinase N3 significantly inhibits tumor growth and lymph node metastasis in an orthotopic mouse model for pancreatic cancers [49]. Our previous study indicates that liposome wrapped shRNA targeting pancreatic and duodenal homeobox 1 (PDX-1) inhibited pancreatic cancer growth in immunodeficiency mice [50]. We also found that liposome/human ZIP4 shRNA treatment reduced the expression of ZIP4 in established xenografts, and inhibited pancreatic cancer growth in an immunodeficient mouse model (unpublished data). In summary, more and more basic research and clinical applications have indicated the great potential of liposome as pharmaceutical or genetic carrier in cancer treatment. Further investigations are needed to optimize this promising carrier to become more effective, nontoxic and highly selective for drug delivery and gene targeting strategy in pancreatic cancer therapy.

\section{Nanoparticle}

The nanotechnology in cancer research has been developed rapidly which significantly advances the diagnosis and treatment of pancreatic cancer. The novel applications of nanotechnology in cancer treatment include drug delivery, new diagnostic imaging system, development of advanced biocompatible materials, and nano-nutriment. Engineered nanoparticles have become an important carrier for the above applications due to its unique structure and characteristics such as a bigger surface to mass ratio compared with other particles, the quantum properties, and the ability to bind, absorb and carry other compounds such as drugs, nucleotides, and proteins. Particles within 1 to 100 nanometers appear to be the optimal size for drug delivery [51,52]. A number of nanoparticle-drug combined formulations (oral or intravenous) are at different stages of clinical trials. Oral nano-delivery systems are developing quickly for its distinct merits in cancer therapy and the ease of administration. Using bioavailable polymeric nanoparticle encapsulated rapamycin as a prototype for oral nano-drug delivery has generated favorable pharmacokinetics and therapeutic effects as shown in a 
xenograft model of human pancreatic cancer. Oral nanoparticle/rapamycin administration results in significant growth inhibition in cancer cells [53].

Nanoparticle can also be used to deliver imaging agents in cancer diagnosis. Semiconductor quantum dots are popular luminescence probes for many biomedical applications because of the particle size (approximately $10 \mathrm{~nm}$ in diameter), high photostability, tunable optical properties, and multimodality. These composite nanomaterials have shown promising efficiency in cancer diagnosis [54]. Manganese-doped quantum dots (Mnd-QDs) with lysine are stably dispersed in aqueous media, which made it easy to combine with targeting molecules. Receptor-mediated delivery of these quantum dots into pancreatic cancer cells has indicated that the multimodal Mnd-QDs could be diagnostic probes for early pancreatic cancer imaging and detection [55]. These studies suggest that quantum dots have a great potential to be a novel safe and efficient optical imaging agent in diagnostic imaging for early cancer detection [56].

One of the major obstacles in cancer therapy is the toxicity and poor bioavailability of the chemotherapy drugs. Nano-materials can reduce the systemic toxicity of the anti-cancer drugs through targeted delivery. A gold nanoparticle delivered gemcitabine (directed by EGFR inhibitor cetuximab) showed significant growth inhibition of pancreatic cancer cell both in vitro and in vivo with minimal toxicity [57]. A PLGA-poloxamer nanoparticle was used as a carrier to transfect a MBD1-siRNA plasmid into BxPC-3 cells and inhibited cell growth and induced apoptosis [58]. A liposomal nanoparticle containing Raf-1 antisense oligonucleotides also showed a therapeutic benefit against human pancreatic tumors in an athymic mouse model [59]. Further studies on the safety, specificity, and delivery efficiency of nanoparticles are warranted in order to extend the application of nanoparticles in cancer treatment [54].

\section{Carbon nanotubes}

Carbon nanotubes (CNTs) hold great promise in drug delivery, imaging, cancer targeting and therapies. It has been proved to be a versatile carrier for a wide variety of agents, including chemotherapy drugs. CNTs are chemically and mechanically stable with easy incorporation and slow release of the delivered drugs. The outside walls of CNTs can be chemically modified to achieve any desired targeting effect. CNTs also have a large surface area, which makes it capable to absorb and incorporate larger amount of drugs. There have not been any major concerns on the cytotoxicity of CNTs, making them a potentially applicable drug delivery vehicle $[11,60]$.

The ability of carbon nanotubes to deliver drugs into tumor cells has generated huge enthusiasm in the potential cancer treatment. Paclitaxol conjugated single-walled carbon nanotubes (SWNT-PTX) led to higher efficacy in suppressing tumor growth than the clinical Taxol treatment in a breast cancer animal model. Prolonged blood circulation and elevated PTX uptake were observed suggesting that SWNT delivery provides enhanced permeability and better drug retention. The incorporated drugs or other molecules are first uptaken by the cancer cells and then slowly released from the SWNTs before excreting via biliary tract without systemic toxicity. When combined with monoclonal antibodies to target specific receptors on cancer cells, the carbon nanotubes complex could be used as targeted agents with better efficiency and less toxicity [61]. A recent study using EGF-directed carbon nanotube delivered cisplatin has shown selective killing of the human head and neck squamous carcinoma cells (HNSCC) which overexpress EGF receptors [62].

The carbon nanotube complexes could also be used for imaging as a biosensor. Single-walled carbon nanotubes conjugated with cyclic Arg-Gly-Asp (RGD) peptides was used as a contrast agent for photoacoustic imaging of xenograft tumors which showed strong photoacoustic signals in the tumors. This may contribute to the non-invasive tumor imaging and monitoring of nanotherapies in living subjects [63]. Moreover, the presence of carbon nanotubes with 
associated metal impurities can be detected in vivo by noninvasive magnetic resonance imaging (MRI) techniques. Gadolinium-based carbon nanotubes have shown 100 times better efficacy than the currently used clinical contrast agents, which will have a significant impact on MRI technology in cancer treatment as an improved contrast agent.

There is growing body of literature recently on carbon nanotube delivered therapy in cancer treatment. CNT-mediated heat release of the drug could produce thermal cytotoxicity to tumor cells in cancer hyperthermia therapy $[64,65]$. Carbon nanotubes have also been used to form stable complexes with small molecules such as siRNAs for delivery into cancer cells [66]. In a lymph node metastasis animal model of pancreatic cancer, we have used modified magnetic multi-walled carbon nanotubes (mMWNTs) to investigate the feasibility of targeting mMWNTs to the lymph nodes through subcutaneous administration, and we found that the degree of positive staining of lymph nodes correlates with the concentration of mMWNTs. Aggregation of magnetic particles was found around the metastatic foci within the lymph nodes, and no particle agglomerates were found in other major organs. Therefore, mMWNTs appear to be a novel lymph node tracer which enables the small lymph nodes to be easily recognized during a surgical resection to remove positive lymph nodes. This finding suggests that subcutaneous administration of mMWNTs may be useful for diagnostic and therapeutic purpose in regional lymph nodes [67].

\section{Potential Targets for Specific Delivery}

Any therapeutic agents and delivery vehicles have side effects at varying degrees when administered systemically. Identification of specific surface receptors or ligands in pancreatic cancer that enables targeted delivery of chemotherapy drugs or other therapeutic agents to pancreatic cancer cells will significantly reduce the toxicity and increase the efficacy of cancer treatment. Several candidate genes have been indicated as potential targets for the specific delivery in pancreatic cancer including EGFR, urokinase plasminogen activator receptor (uPAR), transferrin, ERBB2, CA125, and stem cell markers such as epithelial cell adhesion molecule (EpCAM), CD44, and CD133 (Table 2).

\section{EGFR}

EGFR is overexpressed in majority of human pancreatic cancers. Activation of EGFR could trigger key downstream signaling cascades in cancer cell proliferation, apoptosis, migration, sensitivity to chemo-radiation therapy, and tumor angiogenesis. Moreover, conjugating EGF in a delivery vector carrying anti-cancer drugs or imaging agents can facilitate the specific delivery into cancer cells overexpressing EGFR such as pancreatic cancer cells [62,68]. In a recent study, cisplatin and EGF were attached to single-wall carbon nanotubes (SWNTs) to target squamous cancer cells HNSCC which overexpress EGFR. Through Qdot luminescence and confocal microscopy, it was shown that SWNT-Qdot-EGF bioconjugates was rapidly internalized into the cancer cells, and HNSCC cells were selectively killed in vitro, while tumor growth was regressed in vivo [62]. EGF target delivery system has also been used in cancer molecular imaging diagnosis. An EGF and dye conjugate were delivered into oral tumor cells and tissues, and the presence of oral neoplasia could be easily visualized by an increase in fluorescence contrast compared with normal mucosa [69]. In a colorectal cancer nude mice model, optical imaging probes targeting EGFR (NIR800-EGF) were synthesized and used to evaluate the therapeutic efficacy of cetuximab, an EGFR inhibitor. The NIR800-EGF accumulation in tumors correlated with relative EGFR expression and EGFR occupancy by cetuximab. The imaging approaches could benefit the noninvasive monitoring of the biological effects of EGFR targeted cancer therapy [70]. 
UPAR

Urokinase plasminogen activator receptor (UPAR) is highly expressed on most of pancreatic cancer cells, and can be used as an optimal surface molecule for receptor-targeted therapy in pancreatic cancer. An uPAR-targeted drug or toxin delivery system could selectively kill the uPAR-expressing tumor cells [71,72]. In an orthotopic xenograft model for pancreatic cancer, uPAR-targeted nanoparticles conjugated with a near-infrared dye-labeled fragment bind and accumulated in uPAR highly expressing pancreatic cancer cells. Optical and MRI were used to monitor the uPAR-elevated pancreatic cancer lesions. This novel receptor-targeted nanoparticle is a potential molecular imaging agent for the detection of primary and metastatic pancreatic cancer lesions [72].

\section{Transferrin receptor}

Transferrin receptor (TfR) is overexpressed in many types of cancer cells including breast cancer, prostate cancer, and squamous cell carcinomas, and correlate with the aggressiveness or proliferation of the tumor cells. Addition of the transferrin ( $\mathrm{Tf}$ ) ligand to a cationic liposome complex resulted in significantly increased in vitro and in vivo transfection efficiency in squamous cell carcinoma of the head and neck (SCCHN, 70-80\% transfection rate compared with only $5-20 \%$ by liposome alone). Both p 53 gene and siRNAs have been successfully delivered to the target organs using TfR conjugated liposomes or nanoparticles in treating many types of cancers including pancreatic cancer [9,73-76].

\section{ERBB2}

ERBB2 is a member of the EGFR family of receptor tyrosine kinases, also known as HER-2 or HER-2/neu. HER-2/neu is reported to be overexpressed on the surface of a panel of human pancreatic cancer cell lines and can be used as a therapeutic target. Lyu et al used a single chain Fv antibody (scFv23) targeting HER-2/neu to deliver tumor necrosis factor (TNF) to TNFresistant pancreatic cancer cells, and compared the cell responses to TNF alone, scFv23/TNF, Herceptin, and combinations of scFv23/TNF with various chemotherapeutic agents including 5-FU, cisplatin, doxorubicin, gemcitabine and etoposide. Their results indicated that delivery of TNF to HER-2/neu expressing pancreatic cancer cells using HER-2/neu as a targeting molecule may be an effective therapy for pancreatic cancer especially when utilized in combination with 5-FU [77]. In another study, a nanosized immunoliposome-based delivery complex (scL) has been developed to deliver anti-HER-2 siRNA preferentially to tumor cells, and sensitize human tumor cells to chemotherapeutics by silencing the target gene and affecting its downstream pathways. This delivery method has been shown to significantly inhibit tumor growth in a pancreatic cancer model [78]. The advantage of using HER-2/neu as a target molecule is that it not only benefits pancreatic cancer treatment, but also can apply to other cancer with HER-2/neu overexpression.

\section{CA125}

CA125 is a cell surface associated glycosylated mucin protein, also known as MUC16. CA125 has been used for early detection of ovarian cancer in the past decades, and is also a valuable serum marker in gastrointestinal cancers, including pancreatic cancer. Duska et al have used a photosensitizer chlorin $\mathrm{e}_{6}$ to conjugate to the $\mathrm{F}(\mathrm{ab}$ ') 2 fragment of the CA125 antibody, which serves as a targeting molecule, in combination with cisplatin to treat cisplatin-resistant cells. This treatment showed a synergistic effect on human ovarian cancer cells [79]. Recent studies indicate that CA125 can bind to mesothelin, which is also overexpressed in pancreatic cancer. Targeted therapy using CA125 and maybe in combination with mesothelin could be a promising strategy for drug delivery in pancreatic cancer. 


\section{Stem cell markers}

Tumors contain a few embryonic-like cells, known as cancer stem cells or cancer-initiating cells (CIC), which count for primary and metastatic tumor growth. Therefore, targeting those cells is particularly important to eliminate tumors and prevent from tumor relapse. Gene profiling of cancer stem cells in many tumors have identified several unique markers such as CD24, CD44, CD133, CD166, EpCAM, and integrins. Their functions in cancer stem cell maintenance and activity is largely unknown [80,81]. EpCAM is a carcinoma-associated antigen and is overexpressed on most pancreatic tumor cells but not on normal cells. Salnikov et al have shown that targeting of EpCAM by bispecific antibody EpCAMxCD3 inhibits pancreatic cancer growth by using a BxPC-3 pancreatic carcinoma xenografts model [82]. Adjuvant treatment with monoclonal antibody of EpCAM reduced the 5-year mortality rate among colorectal cancer patients with minimal residual disease [83]. Hong et al found that CD44-positive cells are responsible for gemcitabine resistance in pancreatic cancer cells. After high-dose gemcitabine treatment to eliminate most of the cells, CD44-positive cells proliferated and reconstituted the resistant population of HPAC and CFPAC-1 cells. These data indicate that in therapeutic applications, targeted therapy against CD44 may overcome drug resistance in the treatment of pancreatic cancer [84]. CD133 is a pentaspan transmembrane glycoprotein overexpressed in many solid tumors and has also been indicated as a potential marker for cancer stem cell in gastrointestinal tract [85]. CD133 was found to be highly expressed in more than $50 \%$ of pancreatic cancer, gastric cancer and intrahepatic cholangiocarcinomas, and CD133 expression was shown to be correlated with lymph node metastasis and vascular endothelial growth factor-C expression in pancreatic cancer [86,87]. Recently CD133 has been used as a potential target for antibody-drug conjugates in hepatocellular and gastric cancers. A murine anti-human CD133 antibody conjugated to a potent cytotoxic drug, monomethyl auristatin F, effectively inhibited the growth of Hep3B hepatocellular and KATO III gastric cancer cells [88]. Further studies are warranted for using the stem cell markers as targeting molecules to treat pancreatic cancer.

\section{Current Clinical Trials using Targeted Delivery}

Targeted therapy against specific markers in pancreatic cancer, or targeted drug delivery which use specific markers in pancreatic cancer to deliver chemotherapy or other drugs may significantly improve the current therapies for pancreatic cancer treatment. There are preclinical data that indicate synergistic effects using gemcitabine, erlotinib and capecitabine to treat pancreatic cancer, and several inhibitors against cell surface receptors or cellular factors have also been used for targeted therapy in pancreatic cancer including IGFR inhibitors, antiangiogenic agents (axitinib, sorafenib), other EGFR inhibitors (gefitinib, lapatinib), anti$\mathrm{NF \kappa B}$ agents (curcumin), anti-mesothelin antibody, and anti-integrin antibody (volociximab), etc. [35,36,41,42,89-92]. However, there are very few clinical trials using targeted drug delivery to treat pancreatic cancer. A phase I trial evaluating the safety of Rexin-G gene transfer for advanced pancreatic cancer was initiated in 2005 , in which a tumor targeted gene therapy against cyclin G1 was delivered using a modified virus vector to treat pancreatic cancer. Another phase I study used transferrin as a targeting agent to deliver nanocomplex with siRNA against the M2 subunit of ribonucleotide reductase (CALAA-01) in adults with solid tumors refractory to standard-of-care therapies. Thirty six patients are estimated to enroll from 2008 to 2010. In a recent phase I/II study, a chemotherapy drug Doxorubicin (DOX) is adsorbed to magnetic beads (MTCs), and the MTC-DOX is directed to the area of a tumor. The iron component of the particle makes it possible to direct MTC-DOX to specific tumor sites by placing a magnet on the body surface. It is hoped that MTC-DOX used with the magnet may target the drug directly to liver tumors and provide a treatment to patients with cancers that have spread to the liver. In the future, more specific targeting markers need to be identified to 
help deliver the chemotherapy and other drugs for pancreatic cancer treatment. And the safety and efficacy of those targeted delivery should be tested as well.

\section{Summary}

Pancreatic cancer is a malignant disease with poor prognosis. For almost 20 years, there are no major breakthroughs in early detection and effective treatment for this terrible disease. Biological approaches that target pancreatic cancer at a molecular level are rapidly evolving and represent promising strategies in the diagnosis and treatment of pancreatic cancer. Using a highly efficient, non-toxic, control released delivery system to carry anti-cancer drugs or imaging agents to cancer cells through specific receptors expressed on cancer cell surfaces has been proved to be a novel and effective approach in pancreatic cancer therapy and diagnosis. The safety and specificity of the vectors such as liposomes, nanoparticles, and carbon nanotubes should be further studied.

\section{Acknowledgments}

This work is partially supported by the National Institutes of Health (NIH) Grant R21CA133604 (Li M), and the Dan L. Duncan Cancer Center Cancer Biology Program Pilot Grant (Li M).

\section{References}

[1]. Sultana A, Smith C. Tudur, Cunningham D, Starling N, Tait D, Neoptolemos JP, Ghaneh P. Br J Cancer 2007;96:1183-90. [PubMed: 17406358]

[2]. Ihse I, Permert J, Andersson R, Borgstrom A, Dawiskiba S, Enander LK, Glimelius B, Hafstrom L, Haglund U, Larsson J, Lindell G, Olmarker A, von Rosen A, Svanvik J, Svensson JO, Thune A, Tranberg KG. Lakartidningen 2002;99:1676-80. 1683-5. [PubMed: 12025194]

[3]. O’Reilly EM. Gastrointest Cancer Res 2009;3:S11-5. [PubMed: 19461915]

[4]. El Maalouf G, Le Tourneau C, Batty GN, Faivre S, Raymond E. Cancer Treat Rev 2009;35:167-74. [PubMed: 19027240]

[5]. Burris HA 3rd, Moore MJ, Andersen J, Green MR, Rothenberg ML, Modiano MR, Cripps MC, Portenoy RK, Storniolo AM, Tarassoff P, Nelson R, Dorr FA, Stephens CD, Von Hoff DD. J Clin Oncol 1997;15:2403-13. [PubMed: 9196156]

[6]. Wong HH, Lemoine NR. Pancreatology 2008;8:431-61. [PubMed: 18724071]

[7]. Moore MJ, Goldstein D, Hamm J, Figer A, Hecht JR, Gallinger S, Au HJ, Murawa P, Walde D, Wolff RA, Campos D, Lim R, Ding K, Clark G, Voskoglou-Nomikos T, Ptasynski M, Parulekar W. J Clin Oncol 2007;25:1960-6. [PubMed: 17452677]

[8]. Huang C, Li M, Chen C, Yao Q. Expert Opin Ther Targets 2008;12:637-45. [PubMed: 18410245]

[9]. Xu L, Pirollo KF, Tang WH, Rait A, Chang EH. Hum Gene Ther 1999;10:2941-52. [PubMed: 10609655]

[10]. De Jong WH, Borm PJ. Int J Nanomedicine 2008;3:133-49. [PubMed: 18686775]

[11]. Yang F, Fu de L, Long J, Ni QX. Med Hypotheses 2008;70:765-7. [PubMed: 17910909]

[12]. Xu Y, Szoka FC Jr. Biochemistry 1996;35:5616-23. [PubMed: 8639519]

[13]. Fu X, Tao L, Li M, Fisher WE, Zhang X. Clin Cancer Res 2006;12:3152-7. [PubMed: 16707615]

[14]. Zhi YH, Song MM, Wang PL, Zhang T, Yin ZY. World J Gastroenterol 2009;15:1072-8. [PubMed: 19266599]

[15]. Chen C, Yu Z. Anticancer Res 2009;29:1367-72. [PubMed: 19414389]

[16]. Guillermet-Guibert J, Davenne L, Pchejetski D, Saint-Laurent N, Brizuela L, Guilbeau-Frugier C, Delisle MB, Cuvillier O, Susini C, Bousquet C. Mol Cancer Ther 2009;8:809-20. [PubMed: 19372554]

[17]. Li M, Zhang Y, Bharadwaj U, Zhai QJ, Ahern CH, Fisher WE, Brunicardi FC, Logsdon CD, Chen C, Yao Q. Clin Cancer Res 2009;15:5993-6001. [PubMed: 19755388] 
[18]. Bouvet M, Bold RJ, Lee J, Evans DB, Abbruzzese JL, Chiao PJ, McConkey DJ, Chandra J, Chada S, Fang B, Roth JA. Ann Surg Oncol 1998;5:681-8. [PubMed: 9869513]

[19]. Cascallo M, Calbo J, Gelpi JL, Mazo A. Cancer Gene Ther 2000;7:545-56. [PubMed: 10811472]

[20]. Li M, Zhang R, Li F, Wang H, Kim HJ, Becnel L, Yao Q, Chen C, Fisher WE. J Am Coll Surg 2005;201:571-8. [PubMed: 16183496]

[21]. Li M, Wang X, Li W, Li F, Yang H, Wang H, Brunicardi FC, Chen C, Yao Q, Fisher WE. Cancer Sci 2008;99:2218-23. [PubMed: 18823376]

[22]. Sherr CJ. Cell 2004;116:235-46. [PubMed: 14744434]

[23]. Tamada K, Wang XP, Brunicardi FC. World J Surg 2005;29:325-33. [PubMed: 15891936]

[24]. Evoy D, Hirschowitz EA, Naama HA, Li XK, Crystal RG, Daly JM, Lieberman MD. J Surg Res 1997;69:226-31. [PubMed: 9202675]

[25]. Lohr M, Hoffmeyer A, Kroger J, Freund M, Hain J, Holle A, Karle P, Knofel WT, Liebe S, Muller P, Nizze H, Renner M, Saller RM, Wagner T, Hauenstein K, Gunzburg WH, Salmons B. Lancet 2001;357:1591-2. [PubMed: 11377651]

[26]. Aoki K, Yoshida T, Matsumoto N, Ide H, Hosokawa K, Sugimura T, Terada M. Hum Gene Ther 1997;8:1105-13. [PubMed: 9189768]

[27]. Liu SH, Davis A, Li Z, Ballian N, Davis E, Wang XP, Fisher W, Brunicardi FC. J Surg Res 2007;141:45-52. [PubMed: 17512546]

[28]. Hecht JR, Bedford R, Abbruzzese JL, Lahoti S, Reid TR, Soetikno RM, Kirn DH, Freeman SM. Clin Cancer Res 2003;9:555-61. [PubMed: 12576418]

[29]. Strong JE, Coffey MC, Tang D, Sabinin P, Lee PW. Embo J 1998;17:3351-62. [PubMed: 9628872]

[30]. Himeno Y, Etoh T, Matsumoto T, Ohta M, Nishizono A, Kitano S. Int J Oncol 2005;27:901-6. [PubMed: 16142304]

[31]. Etoh T, Himeno Y, Matsumoto T, Aramaki M, Kawano K, Nishizono A, Kitano S. Clin Cancer Res 2003;9:1218-23. [PubMed: 12631628]

[32]. Strimpakos A, Saif MW, Syrigos KN. Cancer Metastasis Rev 2008;27:495-522. [PubMed: 18427734]

[33]. Sultana A, Smith CT, Cunningham D, Starling N, Neoptolemos JP, Ghaneh P. J Clin Oncol 2007;25:2607-15. [PubMed: 17577041]

[34]. Cascinu S, Verdecchia L, Valeri N, Berardi R, Scartozzi M. Ann Oncol 2006;17(Suppl 5):v14852. [PubMed: 16807445]

[35]. Buchsbaum DJ, Bonner JA, Grizzle WE, Stackhouse MA, Carpenter M, Hicklin DJ, Bohlen P, Raisch KP. Int J Radiat Oncol Biol Phys 2002;54:1180-93. [PubMed: 12419447]

[36]. Bruckner HW, Hrehorovich VR, Sawhney HS. Anticancer Res 2005;25:3637-9. [PubMed: 16101193]

[37]. Gold DV, Modrak DE, Schutsky K, Cardillo TM. Int J Cancer 2004;109:618-26. [PubMed: 14991585]

[38]. Qu CF, Li Y, Song YJ, Rizvi SM, Raja C, Zhang D, Samra J, Smith R, Perkins AC, Apostolidis C, Allen BJ. Br J Cancer 2004;91:2086-93. [PubMed: 15599383]

[39]. Li M, Bharadwaj U, Zhang R, Zhang S, Mu H, Fisher WE, Brunicardi FC, Chen C, Yao Q. Mol Cancer Ther 2008;7:286-296. [PubMed: 18281514]

[40]. Chang K, Pastan I. Proc Natl Acad Sci U S A 1996;93:136-40. [PubMed: 8552591]

[41]. Hassan R, Bullock S, Premkumar A, Kreitman RJ, Kindler H, Willingham MC, Pastan I. Clin Cancer Res 2007;13:5144-9. [PubMed: 17785569]

[42]. Hassan R, Ho M. Eur J Cancer 2008;44:46-53. [PubMed: 17945478]

[43]. Drummond DC, Meyer O, Hong K, Kirpotin DB, Papahadjopoulos D. Pharmacol Rev 1999;51:691743. [PubMed: 10581328]

[44]. Huwyler J, Drewe J, Krahenbuhl S. Int J Nanomedicine 2008;3:21-9. [PubMed: 18488413]

[45]. Zamboni WC. Clin Cancer Res 2005;11:8230-4. [PubMed: 16322279]

[46]. Stathopoulos GP, Boulikas T, Vougiouka M, Deliconstantinos G, Rigatos S, Darli E, Viliotou V, Stathopoulos JG. Oncol Rep 2005;13:589-95. [PubMed: 15756428] 
[47]. Cosco D, Bulotta A, Ventura M, Celia C, Calimeri T, Perri G, Paolino D, Costa N, Neri P, Tagliaferri P, Tassone P, Fresta M. Cancer Chemother Pharmacol. 2009

[48]. Xu JH, Guo XZ, Ren LN, Shao LC, Liu MP. World J Gastroenterol 2008;14:1126-32. [PubMed: 18286698]

[49]. Aleku M, Schulz P, Keil O, Santel A, Schaeper U, Dieckhoff B, Janke O, Endruschat J, Durieux B, Roder N, Loffler K, Lange C, Fechtner M, Mopert K, Fisch G, Dames S, Arnold W, Jochims K, Giese K, Wiedenmann B, Scholz A, Kaufmann J. Cancer Res 2008;68:9788-98. [PubMed: 19047158]

[50]. Liu S, Ballian N, Belaguli NS, Patel S, Li M, Templeton NS, Gingras MC, Gibbs R, Fisher W, Brunicardi FC. Pancreas 2008;37:210-20. [PubMed: 18665085]

[51]. Sajja HK, East MP, Mao H, Wang YA, Nie S, Yang L. Curr Drug Discov Technol 2009;6:43-51. [PubMed: 19275541]

[52]. Sinha R, Kim GJ, Nie S, Shin DM. Mol Cancer Ther 2006;5:1909-17. [PubMed: 16928810]

[53]. Bisht S, Feldmann G, Koorstra JB, Mullendore M, Alvarez H, Karikari C, Rudek MA, Lee CK, Maitra A, Maitra A. Mol Cancer Ther 2008;7:3878-88. [PubMed: 19074860]

[54]. Bharali DJ, Khalil M, Gurbuz M, Simone TM, Mousa SA. Int J Nanomedicine 2009;4:1-7. [PubMed: 19421366]

[55]. Yong KT. Nanotechnology 2009;20:15102. [PubMed: 19417242]

[56]. Yong KT, Ding H, Roy I, Law WC, Bergey EJ, Maitra A, Prasad PN. ACS Nano 2009;3:502-10. [PubMed: 19243145]

[57]. Patra CR, Bhattacharya R, Wang E, Katarya A, Lau JS, Dutta S, Muders M, Wang S, Buhrow SA, Safgren SL, Yaszemski MJ, Reid JM, Ames MM, Mukherjee P, Mukhopadhyay D. Cancer Res 2008;68:1970-8. [PubMed: 18339879]

[58]. Luo G, Jin C, Long J, Fu D, Yang F, Xu J, Yu X, Chen W, Ni Q. Cancer Biol Ther 2009;8:594-8. [PubMed: 19276660]

[59]. Zhang C, Pei J, Kumar D, Sakabe I, Boudreau HE, Gokhale PC, Kasid UN. Methods Mol Biol 2007;361:163-85. [PubMed: 17172711]

[60]. Pastorin G. Pharm Res 2009;26:746-69. [PubMed: 19142717]

[61]. Liu Z, Chen K, Davis C, Sherlock S, Cao Q, Chen X, Dai H. Cancer Res 2008;68:6652-60. [PubMed: 18701489]

[62]. Bhirde AA, Patel V, Gavard J, Zhang G, Sousa AA, Masedunskas A, Leapman RD, Weigert R, Gutkind JS, Rusling JF. ACS Nano 2009;3:307-16. [PubMed: 19236065]

[63]. De la Zerda A, Zavaleta C, Keren S, Vaithilingam S, Bodapati S, Liu Z, Levi J, Smith BR, Ma TJ, Oralkan O, Cheng Z, Chen X, Dai H, Khuri-Yakub BT, Gambhir SS. Nat Nanotechnol 2008;3:55762. [PubMed: 18772918]

[64]. Gannon CJ, Cherukuri P, Yakobson BI, Cognet L, Kanzius JS, Kittrell C, Weisman RB, Pasquali M, Schmidt HK, Smalley RE, Curley SA. Cancer 2007;110:2654-65. [PubMed: 17960610]

[65]. Torti SV, Byrne F, Whelan O, Levi N, Ucer B, Schmid M, Torti FM, Akman S, Liu J, Ajayan PM, Nalamasu O, Carroll DL. Int J Nanomedicine 2007;2:707-14. [PubMed: 18203437]

[66]. Zhang Z, Yang X, Zhang Y, Zeng B, Wang S, Zhu T, Roden RB, Chen Y, Yang R. Clin Cancer Res 2006;12:4933-9. [PubMed: 16914582]

[67]. Yang F, Hu J, Yang D, Long J, Luo G, Jin C, Yu X, Xu J, Wang C, Ni Q, Fu D. Nanomed 2009;4:31730.

[68]. Muslimov GF. Bull Exp Biol Med 2008;145:535-8. [PubMed: 19110611]

[69]. Nitin N, Rosbach KJ, El-Naggar A, Williams M, Gillenwater A, Richards-Kortum RR. Neoplasia 2009;11:542-51. [PubMed: 19484143]

[70]. Manning HC, Merchant NB, Foutch AC, Virostko JM, Wyatt SK, Shah C, McKinley ET, Xie J, Mutic NJ, Washington MK, LaFleur B, Tantawy MN, Peterson TE, Ansari MS, Baldwin RM, Rothenberg ML, Bornhop DJ, Gore JC, Coffey RJ. Clin Cancer Res 2008;14:7413-22. [PubMed: 19010858]

[71]. Liu S, Bugge TH, Leppla SH. J Biol Chem 2001;276:17976-84. [PubMed: 11278833]

[72]. Yang L, Mao H, Cao Z, Wang YA, Peng X, Wang X, Sajja HK, Wang L, Duan H, Ni C, Staley CA, Wood WC, Gao X, Nie S. Gastroenterology 2009;136:1514-25. e2. [PubMed: 19208341] 
[73]. Xu L, Pirollo KF, Chang EH. J Control Release 2001;74:115-28. [PubMed: 11489488]

[74]. Xu L, Tang WH, Huang CC, Alexander W, Xiang LM, Pirollo KF, Rait A, Chang EH. Mol Med 2001;7:723-34. [PubMed: 11713371]

[75]. Xu L, Huang CC, Huang W, Tang WH, Rait A, Yin YZ, Cruz I, Xiang LM, Pirollo KF, Chang EH. Mol Cancer Ther 2002;1:337-46. [PubMed: 12489850]

[76]. Abela RA, Qian J, Xu L, Lawrence TS, Zhang M. Cancer Gene Ther 2008;15:496-507. [PubMed: 18483503]

[77]. Lyu MA, Kurzrock R, Rosenblum MG. Biochem Pharmacol 2008;75:836-46. [PubMed: 18082672]

[78]. Pirollo KF, Rait A, Zhou Q, Hwang SH, Dagata JA, Zon G, Hogrefe RI, Palchik G, Chang EH. Cancer Res 2007;67:2938-43. [PubMed: 17409398]

[79]. Duska LR, Hamblin MR, Miller JL, Hasan T. J Natl Cancer Inst 1999;91:1557-63. [PubMed: 10491432]

[80]. Marhaba R, Klingbeil P, Nuebel T, Nazarenko I, Buechler MW, Zoeller M. Curr Mol Med 2008;8:784-804. [PubMed: 19075676]

[81]. Lee CJ, Li C, Simeone DM. Transl Oncol 2008;1:14-8. [PubMed: 18607507]

[82]. Salnikov AV, Groth A, Apel A, Kallifatidis G, Beckermann BM, Khamidjanov A, Ryschich E, Buchler MW, Herr I, Moldenhauer G. J Cell Mol Med. 2009

[83]. Balzar M, Winter MJ, de Boer CJ, Litvinov SV. J Mol Med 1999;77:699-712. [PubMed: 10606205]

[84]. Hong SP, Wen J, Bang S, Park S, Song SY. Int J Cancer. 2009

[85]. Zou GM. J Cell Physiol 2008;217:598-604. [PubMed: 18651561]

[86]. Caux C, Burdin N, Galibert L, Hermann P, Renard N, Servet-Delprat C, Banchereau J. Res Immunol 1994;145:235-9. discussion 244-9. [PubMed: 7527581]

[87]. Maeda S, Shinchi H, Kurahara H, Mataki Y, Maemura K, Sato M, Natsugoe S, Aikou T, Takao S. Br J Cancer 2008;98:1389-97. [PubMed: 18349830]

[88]. Smith LM, Nesterova A, Ryan MC, Duniho S, Jonas M, Anderson M, Zabinski RF, Sutherland MK, Gerber HP, Van Orden KL, Moore PA, Ruben SM, Carter PJ. Br J Cancer 2008;99:100-9. [PubMed: 18542072]

[89]. Spano JP, Chodkiewicz C, Maurel J, Wong R, Wasan H, Barone C, Letourneau R, Bajetta E, Pithavala Y, Bycott P, Trask P, Liau K, Ricart AD, Kim S, Rixe O. Lancet 2008;371:2101-8. [PubMed: 18514303]

[90]. Brell JM, Matin K, Evans T, Volkin RL, Kiefer GJ, Schlesselman JJ, Dranko S, Rath L, Schmotzer A, Lenzner D, Ramanathan RK. Oncology 2009;76:270-4. [PubMed: 19258727]

[91]. Ouchi KF, Yanagisawa M, Sekiguchi F, Tanaka Y. Cancer Chemother Pharmacol 2006;57:693702. [PubMed: 16362295]

[92]. Rivera F, Lopez-Tarruella S, Vega-Villegas ME, Salcedo M. Cancer Treat Rev 2009;35:335-9. [PubMed: 19131170] 


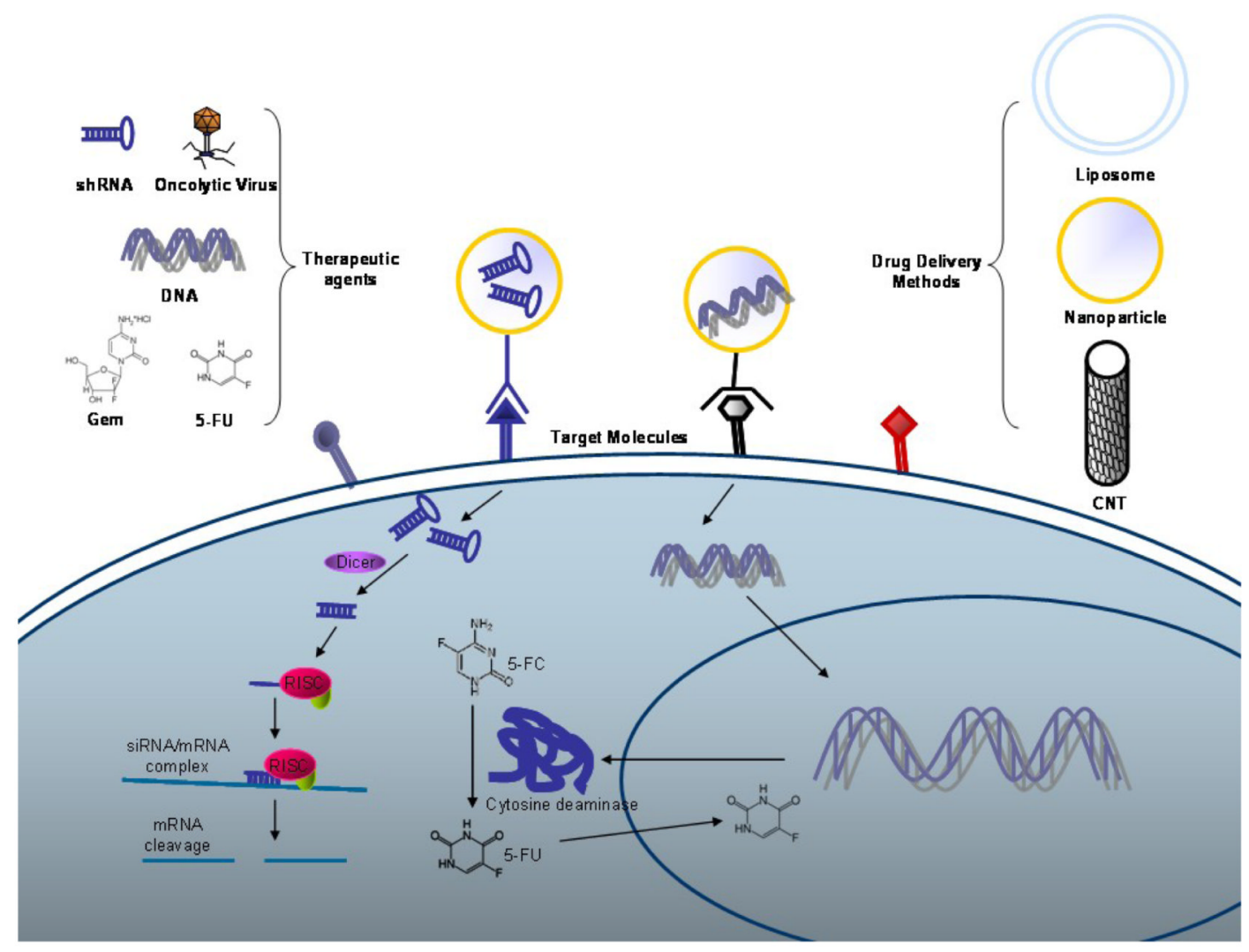

Figure 1. Targeted drug delivery models in pancreatic cancer

Liposomes, nanoparticles, and carbon nanotubes are most commonly used vectors to deliver cancer chemotherapy drugs and other therapeutic agents such as shRNA, tumor suppressor gene, suicide gene, oncolytic virus, small molecule inhibitor and antibody for pancreatic cancer treatment. Specific surface receptors or ligands in pancreatic cancer can be used to enable targeted delivery of the therapeutic agents to reduce the toxicity and increase the efficacy of therapy. A few examples of target molecules include EGFR, uPAR, transferrin, ERBB2, CA125, and stem cell markers such as EpCAM, CD44, and CD133. A representative delivery model in which nanoparticles carrying shRNA or suicide gene conjugated with target molecules, and the corresponding pathways inside the cells are shown. 


\section{Table 1}

Therapeutic Agents for Pancreatic Cancer Treatment.

\begin{tabular}{lll}
\hline Therapeutic Agents & Examples & References \\
\hline siRNAs and shRNAs & MMP-2, HIF-1 $\alpha$, PDX-1, ZIP4, etc & $14,15,16,17,50$ \\
Gene therapy/Suicide genes & p53, SSTR, CD, TK & $9,18,19,20,21,24,25,26,27$ \\
Oncolytic viruses & Adenovirus, HSV, reovirus & $13,28,29,30,31$ \\
Small molecule inhibitors & EGFR inhibitor & $7,32,33$ \\
& & \\
\hline \multirow{2}{*}{ Antibodies } & EGFR, VEGFR, MUC1, MSLN & $35,36,37,38,39,40,41,42$ \\
\hline
\end{tabular}


Table 2

Potential Targets for Specific Delivery.

\begin{tabular}{lll}
\hline $\begin{array}{l}\text { Delivery } \\
\text { Targets }\end{array}$ & Therapeutic Agents and Organ Systems & References \\
\hline EGFR & $\begin{array}{l}\text { Chemotherapy drugs and imaging agents, Pancreas, } \\
\text { colorectal cancer, and } \\
\text { SCCHN } \\
\text { Chemotherapy drugs and imaging agents, Pancreatic } \\
\text { cancer }\end{array}$ & $62,68 \_70$ \\
uPAR & $\begin{array}{l}\text { Gene therapy and shRNA therapy, Breast, prostate } \\
\text { cancer, and SCCHN }\end{array}$ & $9,73,76$ \\
TfR & Cytokine and chemotherapy, pancreatic cancer & 77,78 \\
ERBB2 & Chemotherapy drug, ovarian caner & 79 \\
CA125 & Antibody, pancreatic cancer & $80 \_83$ \\
EpCAM & Cytotoxic drug, hepatocellular and gastric cancers & $85 \_88$ \\
\hline CD133 &
\end{tabular}

